\title{
Praksa na Fakulteti za socialno delo v času izrednih razmer
}

\author{
Izkušnje študentk in mentoric v prvem valu epidemije covida-19
}

\begin{abstract}
Praktično usposabljanje je pomemben del izobraževanja za socialno delo. V času pandemije covida-19je zaradi ukrepov, povezanih z zmanjševanjem širjenja virusa, potrebovaloštevilne prilagoditve (sodelovanje z uporabniki na daljavo, zmanjšanje ur prakse ipd.), to pa je za študentke in mentorice pomenilo nove izzive. V članku predstavljamo doživljanje izvedbe praktičnega usposabljanja za socialno delo $v$ Sloveniji v času prvega vala epidemije covida-19 z vidika mentoric in študentk. Rezultati raziskave kažejo, da se pri deležnikih pojavlja različno zadovoljstvo z izvedbo prakse v spremenjenih okoliščinah. Izzivi študentk so bili povezani predvsem z nemožnostmi za sodelovanje z uporabniki in dodatno obremenjenostjo zaradi prilagoditev študijskega procesa, pri mentoricah pa s tem, kako zagotavljati kakovostno mentorstvo in omogočati pričakovane izkušnje v takšnih okoliščinah. Študentke so zaradi spremenjene situacije pridobile več novih znanj, tako vsebinskih kot tudi tistih, povezanih z uporabo informacijsko-komunikacijske tehnologije. Ugotovitve raziskave tudi kažejo, da je pri spoprijemanju študentk z izzivi na praksi ključna podpora mentoric (s Fakultete za socialno delo in učnih baz), saj jim da znanje, kako se na izzive odzvati.
\end{abstract}

Ključnebesede:praktično usposabljanje, mentorstvo, zadovoljstvo, pandemija, kombinirana raziskava. Dr. Tadeja Kodele je asistentka na Fakulteti za socialno delo. Njeno področje dela so socialno delo z mladimi, participacija otrok in socialno delo z družino. Kontakt: tadeja.kodele@fsd.uni-lj.si.

Dr. Klavdija Kustec je asistentka na Fakulteti za socialno delo. Njeno področje dela so praksa, umetniško izrazna sredstva v socialnem delu, supervizija in socialno delo z mladim. Kontakt: klavdija. kustec@fsd.uni-lj.si

Dr. Tamara Rape Žiberna je socialna delavka, zaposlena kot asistentka na Katedri za raziskovanje in organizacijo Fakultete za socialno delo. Njeno področje dela so timsko delo, praktično usposabljanje in raziskovanje v socialnem delu. Kontakt: tamara.rape@fsd.uni-lj.si.

\section{Field placement at the Faculty of Social Work during extreme circumstances: experiences of students and mentors during the first wave of Covid-19 epidemic}

Practical training is an important part of social work education. During the covid-19 pandemic, measures to contain the spread of the virus required a number of adjustments (cooperation with users remotely, reducing practice hours etc.) that created new challenges for students and mentors. In the article, the experience of conducting practical training for social work in Slovenia during the first wave of the covid-19 epidemic is presented from the perspective of mentors and students. The results of the research show that the stakeholders have different levels of satisfaction with the implementation of the practice in changed circumstances. Students' challenges were mainly related to the inability to collaborate with users, and the additional burden of adapting the study process, and mentors' challenges were related to how to provide quality mentoring and facilitate the expected experience under such circumstances. Due to the changed situation, students acquired several new skills, both in terms of content and the use of information and communication technology. The findings of the research also show that the support of mentors (from the Faculty of Social Work and field placements) is crucial for students to face the challenges in practice as it equips them with the knowledge of how to respond to challenges.

Key words: practical training, mentoring, satisfaction, pandemic, mixed methodology.

Tadeja Kodele, PhD, is a Teaching Assistant at the Faculty of Social Work, University of Ljubljana. Her interests include social work with young people, participation of children, and social work with family. Contact: tadeja.kodele@fsd.uni-lj.si.

Klavdija Kustec, PhD, is a Teaching Assistant at the Faculty of Social Work, University of Ljubljana. Her interests include field placement, artistic expressive means in social work, supervision, and social work with young people. Contact: klavdija.kustec@fsd.uni-lj.si.

Tamara Rape Žiberna, PhD, is a Teaching Assistant at the Chair of Research and Organisation, at the Faculty of Social Work, University of Ljubljana. Her interests include teamwork, field placement, and reasearch in social work. Contact: tamara.rape@fsd.uni-lj.si. 


\section{Uvod}

Pandemija covida-19 je povzročila velike spremembe na različnih življenjskih področjih - socialnem, ekonomskem, izobraževalnem, političnem, kulturnem ipd. Z namenom zajezitve virusa so države namreč omejile gibanje ljudi in odredile zaprtje tako državnih meja kot tudi storitev znotraj države (npr. šolstvo, socialno varstvo, storitvene dejavnosti) (Azman, Singh, Parker in Crabtree, 2020; Dominelli, Harrikari, Mooney, Leskošek in Kennedy Tsonuda, 2020). Življenjske razmere so se še bolj kot za druge poslabšale za tiste ljudi, s katerimi socialne delavke po navadi največ sodelujejo - ljudi na robu družbe, ki trpijo zaradi slabega zdravja, revščine, rasizma in drugih oblik zatiranja in neenakosti.

Kako vzpostaviti in vzdrževati stik z njimi, je bilo osrednje vprašanje številnih socialnih delavk (Azman, Singh, Parker in Crabtree, 2020; Banks idr., 2020). Številne institucije, namenjene uporabnikom storitev socialnega dela (npr. centri za socialno delo, mladinski centri, dnevni centri, dnevno varstveni centri), so namreč marca 2020 zaprle vrata, $v$ njih zaposlene socialne in druge strokovne delavke pa so si za sodelovanje z uporabniki pomagale z informacijsko-komunikacijsko tehnologijo (telefon, e-pošta, spletna orodja). Zaposlene na centrih za socialno delo so osebne stike $\mathrm{z}$ ljudmi izvajale le v nujnih primerih (npr. nasilje $\mathrm{v}$ družini, zaščita otrok). Namestitvene institucije, kot so domovi za stare ljudi, socialnovarstveni zavodi, vzgojni zavodi in materinski domovi, so v času pandemije kljub temu večinoma ohranile obstoječi način dela, a z namenom preprečevanja širjenja virusa prepovedale obiske (Banks idr., 2020; Dominelli, Harrikari, Mooney, Leskošek in Kennedy Tsonuda, 2020; Harrikari, Romakkaniemi, Tiitinen in Ovaskainen, 2021; gl. tudi članek Mešl in Leskošek v tej številki).

Ukrepi za zajezitev širjenja pandemije covida-19 so pomembno vplivali tudi na izobraževanje na vseh ravneh - od predšolske do visokošolske. Šole in univerze so zaprle vrata in tradicionalno poučevanje v učilnici se je preusmerilo na tehnološko podprto e-učenje s pomočjo različnih oblik spletnih učnih aplikacij (npr. Zoom, Loom, Flipgard, Webex). Spletno učenje je tako postalo nova norma, saj je večina univerz z njim nadaljevala do konca študijskega leta (Azman, Singh, Parker in Crabtree, 2020; Kourgiantakis in Lee, 2020; Nadeak, 2020).

Čeprav je spletno učenje študentkam omogočilo neprekinjeno usvajanje znanja v času pandemije, pa ima tudi omejitve, še posebej v okviru pridobivanja praktičnih izkušenj. Socialno delo je dejavna znanost in praktično usposabljanje (v nadaljevanju tudi praksa) je obvezen in pomemben element študija, saj študentkam omogoča, da pridobijo ustrezne praktične kompetence.

Raziskava, izvedena med študentkami socialnega dela v Maleziji o njihovih izkušnjah s spletnim praktičnim usposabljanjem in supervizijo v času pandemije covida-19, je pokazala, da so bile obremenitve v tem času večje od običajnega praktičnega usposabljanja in supervizije. Študentke so dobivale več nalog in so torej doživljale večji stres (Morley in Clarke, 2020). Na navedeno opozarja tudi več raziskav iz evropskega prostora (gl. npr. Zurlo, Cattaneo Dela Volta in Vallone, 2020; Nacionalni inštitut za javno zdravje, 2021; Sarbo in Unwin, 2021), ki ugotavljajo, da se v obdobju pandemije med študentkami pojavlja visoka stopnja tesnobe in zaskrbljenosti zaradi študija 
na daljavo (zmanjšanje motivacije za študij) in drugih omejitev (zaprtje študentskih domov, nezmožnost opravljanja študentskega dela, pomanjkanje stika s prijatelji, strah pred negotovo prihodnostjo ipd.).

Tudi v Sloveniji smo poleti 2020 zbrali podatke o tem, kako so praktično usposabljanje $v$ času prvega vala doživele študentke Fakultete za socialno delo Univerze v Ljubljani (FSD) in njihove mentorice. Podobno kot ugotavljajo tuji avtorji (Morley in Clarke, 2020; Buchanan in Bailey-Belafonte, 2021; Dempsey idr., 2021) smo bili zaradi pandemije tudi na FSD primorani hitro prilagoditi praktično usposabljanje. Spremenjeno oz. okrnjeno delovanje organizacij, v katerih študentke navadno opravljajo praktično usposabljanje, je namreč prineslo predvsem izziv, kako v predvidenem časovnem okviru za prakso študentkam omogočiti sodelovanje z uporabniki in torej opravljanje nalog z namenom pridobitve zahtevanih kompetenc.

Cilj članka je (na podlagi ocen zadovoljstva, doživetih ovir, doseganja ciljev prakse ipd.) predstaviti potek in specifike praktičnega usposabljanja študentk v času prvega vala epidemije covida-19. V uvodu naprej opišemo pomen praktičnega usposabljanja za socialno delo in kakšne prilagoditve so bile potrebne $v$ času prvega vala epidemije. V nadaljevanju prikažemo ugotovitve o pogledu študentk in mentoric, tako na učnih bazah kot tudi na fakulteti, na opravljanje študijske prakse na področju socialnega dela v času epidemije in raziščemo, kaj pridobljene izkušnje pomenijo tudi širše - za socialno delo v času drugih izrednih razmer.

\section{Pomen praktičnega usposabljanja na področju socialnega dela}

Praktično usposabljanje v socialnem delu je sestavni del učnih načrtov šol za socialno delo v številnih državah (Mesec, 2015; Walsh, Gulbrandsen in Lorenzetti, 2019). Shulman (2005) poda zanimivo ilustracijo praktičnega usposabljanja, češ da vključuje glavo (znanje in spoznanja), srce (čustva in etiko) in roko (učenje z delom). S tem je želel avtor poudariti, da je poučevanje proces, torej ne le intelektualna dejavnost, temveč tudi dejavnost, ki vključuje čustvene in telesne reakcije.

Izkušnje, pridobljene med praktičnim usposabljanjem, so ključne, saj lahko študentke na ta način teoretsko in konceptualno znanje, naučeno v predavalnici, uporabijo v resničnih okoljih in z izkustvenim učenjem razvijejo lastne kompetence za prakso socialnega dela (Mesec idr., 2019; Petra, Tripepi in Guardiola, 2020). S pomočjo praktičnih izkušenj študentke prav tako krepijo znanje o poklicu ter o vrednotah in etiki socialnega dela (Azman, Singh, Parker in Crabtree, 2020).

Tako v Sloveniji kot v tujini (Bogo, 2015; Cleak, Hawkins, Laughton in Williams, 2015), študentke opisujejo svoje praktično usposabljanje kot svojo najpomembnejšo učno izkušnjo, saj ob podpori socialnih delavk v praksi (na specifičnih področjih, ki jih zanimajo) v resničnih življenjskih situacijah dobijo vpogled tako v samo prakso socialnega dela na različnih področjih, v uporabo 
in delovanje posameznih konceptov in oblik dela (glej npr. Rape Žiberna, 2019, str. 113) kot tudi v potrebnost določenih kompetenc. Razvijanje kompetenc za prakso socialnega dela je zapleteno in zahteva kombinacijo procesnih kompetenc, kot so znanje in spretnosti, skupaj z metakompetencami, kot sta samozavedanje in samorefleksija (Kourgiantakis idr., 2020). Študentke morajo razviti tudi medkulturne kompetence, naučiti se morajo povezati teorijo s prakso in uporabiti načela socialne pravičnosti pri delu z uporabniki (Lee, Bogo in Tsang, 2020). Pri tem jim zelo pomagajo izkušene socialne delavke, saj jim zagotavljajo mentorsko podporo in pomoč ter spremljajo njihov napredek in pridobivanje kompetenc (Raskin, Wayne in Bogo, 2008; Cleak in Smith, 2012; Goodyear, 2014; Bogo, 2014, 2015; Nordstrand, 2017; McSweeney in Williams, 2018). Praksa in mentorska podpora (v okviru prakse) sta navadno tudi precej dobro ocenjena elementa usposabljanja za socialno delo. To kaže, da študentke prepoznajo prispevek prakse k občutku o pridobljenih kompetencah za socialno delo v praksi (Rape Žiberna in Žiberna, 2017).

Na FSD se zavedamo pomena pridobivanja praktičnih izkušenj za kompetentno delo $\mathrm{v}$ praksi socialnega dela. Zato je praksa sestavni del učenja že od začetka usposabljanja za socialno delo (pred 66 leti). Študentke tako na podlagi lastnih izkušenj spoznavajo delo v različnih organizacijah, ki jih imenujemo učne baze, in prihajajo v stik z zgodbami številnih uporabnic in uporabnikov.

Oblika in obseg praktičnega usposabljanja sta odvisna od letnika študija, praksa pa poteka tako v okviru dodiplomskega (okrog 600 ur na 1. bolonjski stopnji) kot tudi podiplomskega študija (okrog 80 ur na 2. bolonjski stopnji). V okviru vsakega letnika morajo študentke izvesti številne praktične naloge in jih zbrati v t. i. učno mapo. Z namenom čim večje podpore študentk pri pridobivanju raznovrstnih kompetenc je bil leta 2007 ustanovljen Center za praktični študij. Skrbi za organiziranje in izvedbo praktičnega usposabljanja (Mesec, 2015) in izdaja priročnike za posamezni letnik.

Praktično usposabljanje poteka za 1. in 2. letnik enkrat na teden (po navadi po nekaj ur ob ponedeljkih), prav tako pa je nato še teden strnjene prakse $\mathrm{v}$ maju. V 3. in 4. letniku poteka praksa v strnjeni obliki - v 3. letniku v obsegu šestih tednov, $v 4$. letniku $v$ obsegu štirih tednov (ko študentke na fakulteti nimajo drugih organiziranih oblik pedagoškega dela). Študentke imajo možnost opravljanja prakse na različnih področjih socialnega varstva pa tudi na drugih področjih (npr. vzgoje in izobraževanja, zdravstva, zaposlovanja). Študentke si na podlagi lastnih osebnih zanimanj učno bazo izberejo iz vnaprej pripravljenega seznama (vsako študijsko leto ga na novo pripravi vodja Centra za praktični študij glede na izražen interes učnih baz za to, da so pripravljene sprejeti študentke na prakso) ali pa se z učno bazo same dogovorijo (gl. tudi Mesec, 2015; Rape Žiberna in Žiberna, 2017).

Kljub že več desetletij trajajočem in ustaljenem sistemu praktičnega usposabljanja je njegova ključna pomanjkljivost neurejeno financiranje (Mesec, 2015, str. 248). Kot navajata tudi Govekar-Okoliš in Gruden (2011), nimamo npr. sistemsko urejenega statusa mentorske organizacije. Pojavljajo se tudi izzivi, povezani z izborom najboljših učnih baz, mentoric. Kot izhaja iz Rape 
Žiberna in Žiberna (2017), mentorstva opravljajo tudi mentorice, ki imajo zelo malo ali celo nič (dopolnjenih) let delovnih izkušenj na področju socialnega dela. V nasprotju z nekaterimi drugimi državami (gl. Rape Žiberna in Žiberna, 2017, str. 199) v Sloveniji nimamo predpisano, koliko ur praktičnih izkušenj morajo študentke pridobiti v katerem sektorju ali na katerem področju, tako da si lahko študentke prosto izbirajo tako vrsto učne baze kot tudi področje dela.

\section{Praktično usposabljanje v času pandemije covida-19}

V številnih državah so poročali, da je bilo treba v času pandemije covida-19 prilagoditi potek praktičnega usposabljanja, predvsem tako, da so študentke začele delati na daljavo in pri tem še bolj pospešeno uporabljati informacijskokomunikacijsko tehnologijo; zmanjšali so število opravljenih ur prakse za $20 \%$ ali pa omogočili, da študentke opravljajo prakso v domačem kraju s povečano supervizijsko podporo (Amadasun, 2020; Kourgiantakis in Lee, 2020; Morley in Clarke, 2020; Nadeak, 2020; Buchanan in Bailey-Belafonte, 2021; Harrikari, Romakkaniemi, Tiitinen in Ovaskainen, 2021).

Tako socialne delavke kot tudi študentke so se pri sodelovanju z uporabniki na daljavo srečevale s številnimi izzivi. Vzpostavljanje delovnega odnosa z uporabniki je bilo oteženo, težje si je bilo razlagati situacije uporabnikov, izraziti empatijo, jim zagotavljati čustveno podporo. Izredne razmere so od socialnih delavk zahtevale tudi hitro prilagajanje in odzivanje na dogodke, reševanje težav, pridobivanje novega znanja in uporabo tega v praksi. To je po eni strani pomenilo, da so poskušale čim bolj ažurno reševati težave, ki so se pojavljale tudi zaradi oteženega dostopa do interneta ali neusposobljenosti za delo na daljavo (tako pri študentkah kot pri uporabnikih) (Harrikari, Romakkaniemi, Tiitinen in Ovaskainen, 2021), po drugi strani pa morale odpravljati manko znanj za uporabo teh orodij. Pri tem so se socialne delavke (in upamo si trditi, tudi študentke) srečevale z različnimi etičnimi dilemami, kako ohraniti zaupanje, zasebnost, dostojanstvo in avtonomijo uporabnikov storitev v odnosih na daljavo; kako uravnotežiti pravice in potrebe uporabnikov in socialnih delavk; z dilemami, ali politike delujejo v interesu uporabnikov storitev; kako poiskati podporo zase (v obliki supervizij, intervizij) (Banks idr., 2020; gl. tudi Sobočan v tej številki).

Tudi v Sloveniji smo spomladi 2020 kot odziv na spremenjene razmere za opravljanje praktičnega usposabljanja v okviru Centra za praktični študij oblikovali številne prilagoditve za izvedbo same prakse, kot so: zmanjšanje obsega ur, prilagoditev nalog, oblikovanje nove, razmeram prilagojene naloge (v 3. letniku), prilagoditev vsebine prakse, podaljšanje terminov opravljanja prakse, dodatno spodbujanje študentk za opravljanje prakse v domačem okolju. Kljub spremenjenim razmeram smo študentkam skušali omogočiti dostop do številnih možnosti in izkušenj (zagotavljanje psihosocialne in učne pomoči šolajočim na daljavo, sodelovanje s starimi ljudmi prek videoklicev ali dopisovanja, pomoč civilni zaščiti ipd.), ki so jim omogočile napredovanje, usposobljenost ter pridobivanje kompetenc, predvsem z učenjem na podlagi ravnanja (Kodele in Mešl, 2015).

Pandemija covida-19 je leta 2020 torej zaznamovala ves svet in skoraj čez noč spremenila delovanje ustanov, kjer se izvaja socialno delo. Zato se 
je spremenilo tudi praktično usposabljanje študentk socialnega dela. Ukrepi, povezani s preprečevanjem širjenja virusa, so zahtevali hiter odziv na spremenjene razmere in drugačno organizacijo prakse. To je vplivalo na vse deležnike prakse - študentke, mentorice (z učnih baz in FSD) ter uporabnike (ki pa v našo raziskavo niso vključeni).

V članku želimo raziskati, s kakšnimi izzivi so se mentorice ( $\mathrm{z}$ učnih baz in FSD) ter študentke ( $\mathrm{v}$ nadaljevanju tudi deležniki ${ }^{1}$ ) srečevale med prakso $\mathrm{v}$ času prvega vala epidemije in kakšno je bilo njihovo zadovoljstvo z organizacijo, izvedbo in doseganjem ciljev prakse. To nas zanima, ker želimo odgovoriti na vprašanje, ali je študentkam kljub izzivom, ki jih je za njihovo praktično usposabljanje pomenila epidemija, uspelo doseči cilje prakse in kakšno je bilo zadovoljstvo s prakso pri različnih deležnikih, z namenom ovrednotenja praktičnega usposabljanja v izrednih razmerah in priprave predlogov za izboljšanje takšnega delovanja v prihodnje.

Postavile smo si tri raziskovalna vprašanja:

1. Kakšno je zadovoljstvo različnih deležnikov praktičnega usposabljanja v času prvega vala epidemije covida-19?

2. S kakšnimi izzivi so se deležniki srečevali na praksi?

3. Koliko so se (kljub spremenjenim razmeram) uresničila pričakovanja različnih deležnikov?

\section{Metodologija}

\section{Populacija in vzorec}

Populacija so bile strokovne delavke, ki so bile v študijskem letu 2019/2020 mentorice (z učnih baz na območju celotne Slovenije in s FSD) študentkam na dodiplomskem študiju, in vse študentke prvih treh letnikov dodiplomskega študija. Po podatkih Centra za praktični študij je bilo v navedenem študijskem letu 222 aktivnih mentoric (torej takšnih, ki so zagotavljale mentorstvo vsaj eni študentki FSD) in 8 mentoric $s$ fakultete. Po podatkih Referata za študentske zadeve pa je bilo v vse tri letnike v študijskem letu 2019/2020 skupaj vpisanih 372 študentk.

Vsem deležnikom smo junija 2020 poslali povabilo za sodelovanje v spletni anketi z namenom evalvacije študijske prakse $\mathrm{v}$ času prvega vala epidemije covida-19. Povabilu se je odzvalo 114 (malo več kot $51 \%$ ) mentoric z učnih baz, pridobili pa smo tudi 8 izpolnjenih vprašalnikov od mentoric s FSD. Izmed 114 mentoric z učnih baz jih je bilo več kot 90 \% ženskega spola (pri mentoricah na fakulteti je ta odstotek nekoliko nižji in znaša $75 \%$ ), povprečna starost anketiranih mentoric $z$ učnih baz pa znaša 40,46 let. $V$ povprečju so imele sodelujoče mentorice $z$ učnih baz malo več kot 11 let delovne dobe na področju socialnega dela. Ker med mentoricami ( $\mathrm{z}$ učnih baz in fakultete) ni večjih razlik, v predstavitvi rezultatov skupine ne obravnavamo ločeno.

1 Mentorice (s FSD in učnih baz) in študentke. 
V raziskavi je sodelovalo tudi 97 študentk ( $26 \%$ populacije) ${ }^{2}$, med katerimi smo v zbiranje podatkov pritegnili večinoma študentke 3 . letnika (43\%) in študentke 1. letnika (39\% sodelujočih), $15 \%$ vseh so študentke 2 . letnika in $3 \%$ študentke 4. letnika. Na splošno se sicer vzorec zdi dokaj nereprezentativen (v primerjavi z numerusi celotne populacije), vendar je cilj analize pregled stanja in dogajanja pri praktičnem usposabljanju v času prvega vala epidemije, ki se je v Sloveniji pojavil marca 2020, ko je večina študentk 4. letnika prakso že končala, 1. in 2. letnik pa sta imela (vsaj del) prakse tudi že opravljen. Zato nam je bilo v pridobivanje podatkov ključno zajeti predvsem čim večji delež študentk iz 3. letnika (ki so nekako najbolj polno doživele učinke epidemije na praktično usposabljanje). Navedeno je treba upoštevati pri branju rezultatov v nadaljevanju.

\section{Instrument in metoda zbiranja podatkov}

Podatki so bili zbrani v okviru evalvacije prakse na FSD v času prvega vala epidemije covida-19 v študijskem letu 2019/2020. Pri pripravi vprašalnika smo sodelovale Amra Šabić, Tamara Rape Žiberna, Tadeja Kodele in Klavdija Kustec. Izvedene so bile tri spletne ankete - ena za študentke, druga za mentorice z učnih baz, tretja pa za mentorice iz fakulteti. Tako smo vključile vidike večine deležnikov praktičnega usposabljanja. Vprašalniki za vse tri skupine deležnikov so vsebovali več deset vprašanj (različnih tipov), zbiranje podatkov pa je potekalo od julija do septembra 2020. Za namen tega članka predstavljamo odgovore le na nekatera vprašanja iz vseh treh vprašalnikov (glede ne/zadovoljstva s prakso, ne/uresničitve pričakovanj, izzivov).

\section{Obdelava podatkov}

Podatke, pridobljene z odgovori na zaprta vprašanja, smo obdelale z univariatno opisno statistiko, znotraj katere smo izračunavale povprečja $(\mathrm{M})$ in standardne odklone (sd), ter z bivariatno opisno statistiko, znotraj katere smo za ugotavljanje korelacije uporabile Pearsonov koeficient linearne korelacije (r). Ponekod smo za potrebe analize oblikovale sestavljene spremenljivke (indekse). Za obdelavo in prikaz podatkov pa smo uporabile programa SPSS 25 in MS Excel. Podatke, pridobljene $\mathrm{z}$ odgovori na odprta vprašanja, smo analizirale po metodi kvalitativne analize, s pomočjo programa za analizo MAXQDA Plus. V prvi fazi smo najprej besedilo glede na opredeljena raziskovalna vprašanja kategorizirale $\mathrm{v}$ posamezne tematske sklope, jih vnesle v program MAXQDA in jih razdelile v več

2 Odstotek odziva oz. sodelujoče populacije v spletni anketi se morda zdi majhen, a po naših izkušnjah presega povprečne odstotke odzivov (7-20 \%) v podobnih zbiranjih podatkov na populaciji študentk FSD (z izjemo anketiranja o študijskem procesu prek spletnega referata, kjer so odstotki sodelovanja občutno večji, med 68 in 88 \%). Opažamo torej majhen interes študentk za sodelovanje $v$ takem zbiranju podatkov (zdi se, da so jim bližje bolj osebni načini zbiranja podatkov), to pa je v predstavljeni raziskavi gotovo pomanjkljivost. Tudi nekatere druge univerze sicer poročajo (University of California, 2021), da je povprečni odstotek odziva študentk na spletne ankete med 22 in 40, raziskave pa kažejo na precej velike razlike pri odzivanju na spletne ankete pri študentkah (odzivnost med $17 \%$ in 83 \%) (gl. npr. Tashfeen, 2018). 
podkategorij in kod. $V$ drugi fazi smo določile splošno zastopanost posameznih kod v celotnem besedilu (torej številčnost pojavljanja kod v celotnem besedilu in glede na to, $v$ koliko dokumentih se določena koda pojavlja). $\mathrm{V}$ zadnji fazi pa smo s pomočjo opisane kategorizacije še vsebinsko analizirale besedilo. Zaradi varovanja osebnih podatkov smo imena in druge osebne podatke spremenile.

\section{Rezultati}

Področje dela pri praktičnem usposabljanju na FSD v času prvega vala epidemije covida-19 je nekoliko drugačno, kot izhaja iz rezultatov predhodne raziskave, opravljene leta 2015 (gl. Mesec, 2015, str. 241). V obdobju pred epidemijo so $\mathrm{z}$ več kot $25 \%$ kot učne baze prevladovali centri za socialno delo, sledilo pa je (z več kot $20 \%$ ) področje otrok in mladostnikov ter (z $20 \%$ ) področje starih ljudi, v času epidemije pa je med učnimi bazami močno prevladovalo področje otrok in mladostnikov (z $51 \%$ ), s $33 \%$ pa sledi področje dela na centrih za socialno delo in s $16 \%$ nato še šolsko svetovalno delo s podobnim odstotkom kot pred epidemijo. Veliko zmanjšanje pa se je (glede na ukrepe in stanje dokaj pričakovano) zgodilo na področju starih ljudi, saj se je delež učnih baz na tem področju zmanjšal na zgolj 3 \%. Nekoliko se je v času epidemije (v primerjavi z letom 2015) povečal tudi delež učnih baz s področja duševnega zdravja, zmanjšal pa delež s področja zasvojenosti.

\section{Zadovoljstvo s prakso}

Pri študentkah so se na vseh postavkah zadovoljstva (ki so razvidne iz grafa 1) pojavljale vse ocene na 5-stopenjski lestvici (pri vseh izračunih, ocenah v nadaljevanju 1 pomeni minimum ali veliko nezadovoljstvo in 5 maksimum ali veliko zadovoljstvo). Študentke so najbolj soglašale pri ocenjevanju splošnega zadovoljstva (sd=1), največjo razpršenost podatkov pa ima postavka Zadovoljstvo s fleksibilnostjo, možnostjo prilagajanja nalog učni bazi (UB) (sd=1,39). To pomeni, da so si bile študentke najmanj enotne pri ocenjevanju te postavke. V povprečju znaša splošno zadovoljstvo s prakso 3,66, se pravi, da so se študentke iz sredinske ocene nagibale k zadovoljstvu s prakso. Najnižje povprečne ocene (pod sredinsko vrednostjo 3) so študentke prisodile postavkama Zadovoljstvo z izvedljivostjo nalog v razmerah covida-19 $(M=2,77)$ in Zadovoljstvo s številom nalog $(M=2,9)$, z najvišjimi povprečnimi oceni pa so študentke ocenile zadovoljstvi s podporama obeh mentoric $(\mathrm{M}(\mathrm{FSD})=4,39$ in $\mathrm{M}(\mathrm{UB})=4,22)$ ter Zadovoljstvo s ponudbo učnih baz $(M=4,06)$.

Tudi analiza odprtih odgovorov študentk je pokazala, da so bile študentke s prakso najbolj zadovoljne prav zaradi podpore mentoric na učni bazi in fakulteti (koda se pojavi v več kot polovici analiziranih dokumentov).

Dosegljivost mentoric - tako na učni bazi kot tudi na FSD, njihova podpora, nasveti, pohvale, pomoč, deljenje lastnih izkušenj. (A3.Š3) ${ }^{3}$

3 Šifra opredeli številko dokumenta oz. anketnega vprašalnika. Š pomeni, da se dokument nanaša na odgovore študentk, MUB na mentorice (M) z učnih baz (UB), MFSD pa na mentorice (M) s FSD. 
Zadovoljne so bile tudi z na praksi pridobljenim novim znanjem in izkušnja$\mathrm{mi}$, predvsem za delo $\mathrm{v}$ času izrednih razmer (koda se pojavi v tretjini vseh analiziranih dokumentov).

Pridobila sem ogromno novih izkušenj in dobila vpogled v temo "socialno delo v izrednih razmerah". (A48.Š)

Študentke so navajale še posamezne postavke zadovoljstva, kot so zadovoljstvo $\mathrm{z}$ učno bazo, $\mathrm{z}$ vzpostavitvijo in vzdrževanjem delovnega odnosa $\mathrm{z}$ uporabniki, $\mathrm{s}$ prilagoditvijo fakultetne prakse izrednim razmeram. Po drugi strani pa so nekatere študentke v svojih odgovorih opozorile na stvari, ki bi jih želele pri organizaciji prakse spremeniti (npr. želele bi si več obveščanja fakultete o poteku prakse, več podpore pri opravljanju prakse in pri iskanju učnih baz, naloge za prakso so se jim zdele preobsežne ali pa nanje po izdelavi niso prejele nobene povratne informacije mentorice na fakulteti, občutile so pritisk, da morajo z uporabniki sodelovati na daljavo, osredotočenost prakse zgolj na zagotavljanje učne pomoči).

Razumem, da smo se znašli v razmerah, ko je bil tudi FSD nemočen, vendar smo bile študentke preveč prepuščene same sebi in dobri volji učnih baz. Sama dolgo nisem vedela ali bom prakso na centru za socialno delo lahko opravljala ali ne, medtem nisem dobila s strani faksa nobene podpore, razen da naj »čakam, če se situacija spremeni«. Pojasnila sem, da bom žal prakso opravljala tudi še v septembru, s čimer moj mentor ni bil zadovoljen, se mi pa ne zdi fer, ker dobro ve, da se preživljam sama, torej moram prakso razporediti tako, da ne vpliva preveč na moj zaslužek. (A65.Š)

Povprečno splošno zadovoljstvo mentoric s prakso na FSD znaša 4,2, to pomeni, da so bile mentorice v povprečju s prakso zadovoljne. To povprečje tudi ne odstopa od izmerjenega v »običajnih razmerah« v študijskem letu 2014/20154 (gl. npr. Rape Žiberna in Žiberna, 2017, str. 209). Mentorice so si bile v svojih odgovorih tudi precej enotne (večina standardnih odklonov pri ocenah mentoric je pod 1), na nekaj postavkah pa se skrajna vrednost velikega nezadovoljstva niti ne pojavi. Nobena povprečna ocena mentoric ni na negativni strani (nižja od 3). Najnižje povprečno zadovoljstvo (s povprečno oceno nižjo od 3,5) pa sta dosegli postavki Zadovoljstvo z odzivanjem drugih deležnikov na spremembe razmer $(\mathrm{M}=3,49)$ in Zadovoljstvo $\mathrm{z}$ izvedljivostjo nalog $\mathrm{v}$ razmerah covida-19 $(M=3,38)$. Mentorice so v povprečju najbolj zadovoljne s fleksibilnostjo in možnostjo prilagajanja nalog na učnih bazah $(M=4,15)$, odzivanjem študentk na spremembe razmer $(M=4,08)$ in terminom izvajanja prakse $(M=4,04)$.

Primerjava zadovoljstva s prakso, predstavljena v grafu 1, pokaže, da so mentorice v povprečju zadovoljnejše (njihove ocene pa so si tudi bolj enotne) z izvedbo prakse v študijskem letu 2019/2020 kot študentke, saj je povprečna ocena splošnega zadovoljstva mentoric kar za 0,5 točke višja od povprečne ocene splošnega zadovoljstva študentk. Mentorice so pri vseh postavkah imele večje povprečno zadovoljstvo kot študentke, največje razlike $v$ povprečnih ocenah mentoric in študentk pa so pri zadovoljstvih, povezanih z nalogami, njihove izvedljivosti $v$ razmerah covida-19 in terminom izvajanja prakse.

$4 \quad \mathrm{~V}$ predstavljeni raziskavi je sicer uporabljena 10-stopenjska ocenjevalna lestvica (in ocena zadovoljstva znaša 8,385), to pa ob preračunu na 5-stopenjsko lestvico pomeni oceno 4,282. 
Graf 1: Primerjava zadovoljstva mentoric in študentk ( $n=36-97)$.

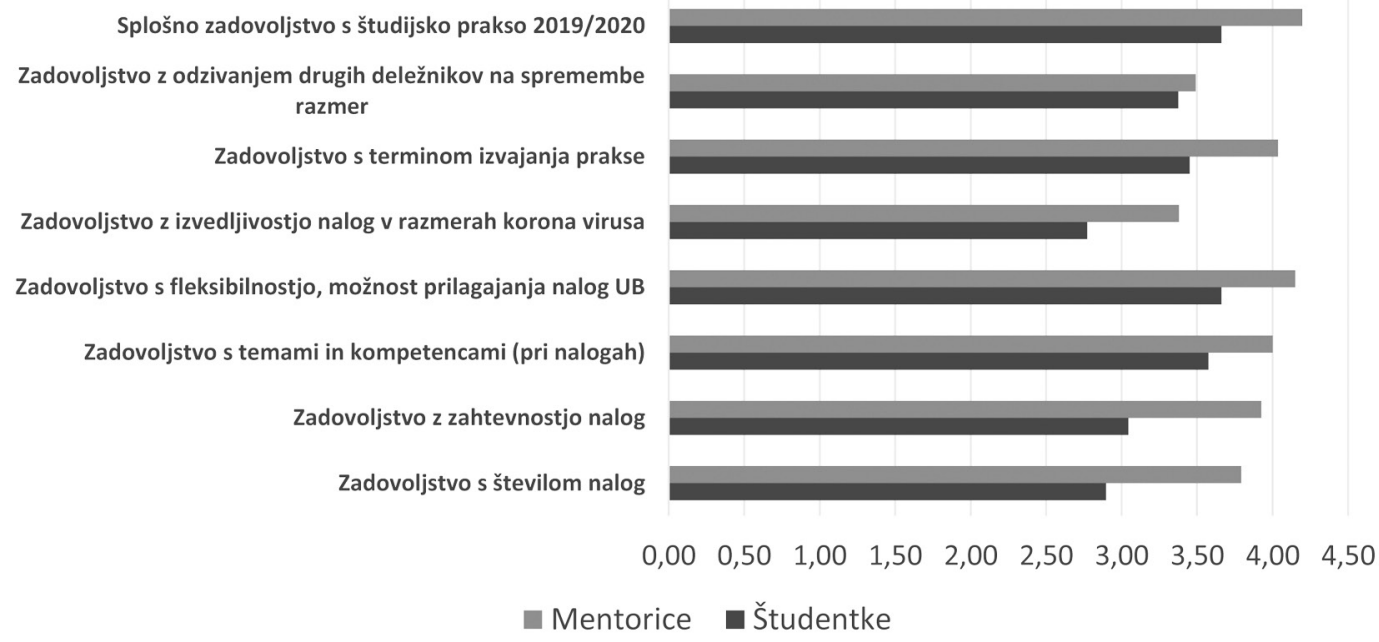

Uresničitev pričakovanj glede izvedbe prakse in doseganje ciljev prakse

Študentke smo v anketi prosili, naj poleg zadovoljstva ocenijo tudi, koliko je bila mentorska podpora ustrezna in cilji doseženi. Kot je razvidno iz grafa 2, so študentke v povprečju pri vseh postavkah ocenile, da so precej pridobile, najvišji povprečni oceni pa sta dobili postavki Podpora mentorice na FSD za praktično delo $(M=4,38)$ in Podpora mentorice na FSD za uspešno izvedbo nalog pri praksi $(M=4,37)$. Študentke so si bile najbolj enotne pri ocenjevanju postavke Seznanitev z delom/delovanjem organizacije, saj ta ni prejela nobene ocene $1(\mathrm{sd}=0,81)$.

Postavke (graf 2), ki so bile zelo neposredno povezane $\mathrm{z}$ mentorico (oz. v katerih je v postavki mentorica navedena), so pri ocenah študentk v zmerni sorazmerni korelaciji z ocenami zadovoljstva s prakso ( $\mathrm{r}$ od 0,432 do 0,545), to pomeni, da so študentke, ki so doseganje ciljev oz. ustreznost podpore ocenjevale

Graf 2: Študentske ocene doseganja ciljev in ustreznost podpore na praksi v študijskem letu $2019 / 2020$ ( $n=81$ in 82).

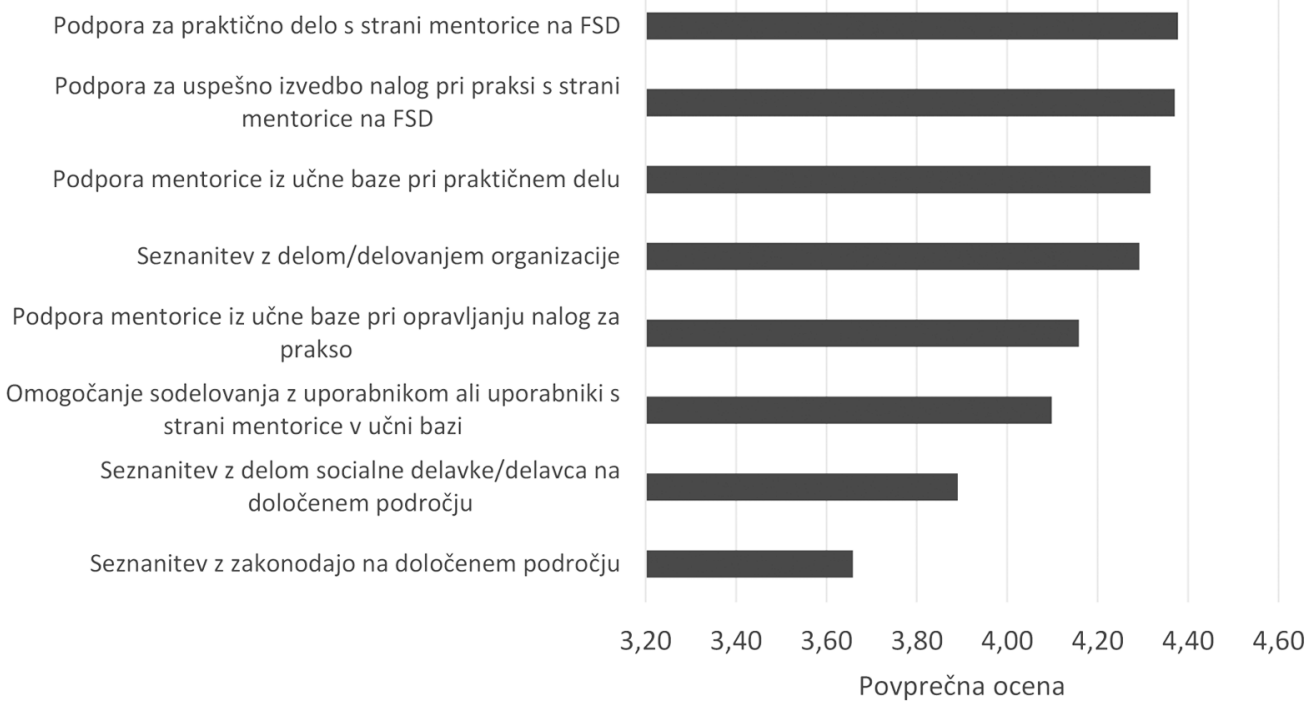


Graf 3: Primerjava doseganja pričakovanj med študentkami in mentoricami.

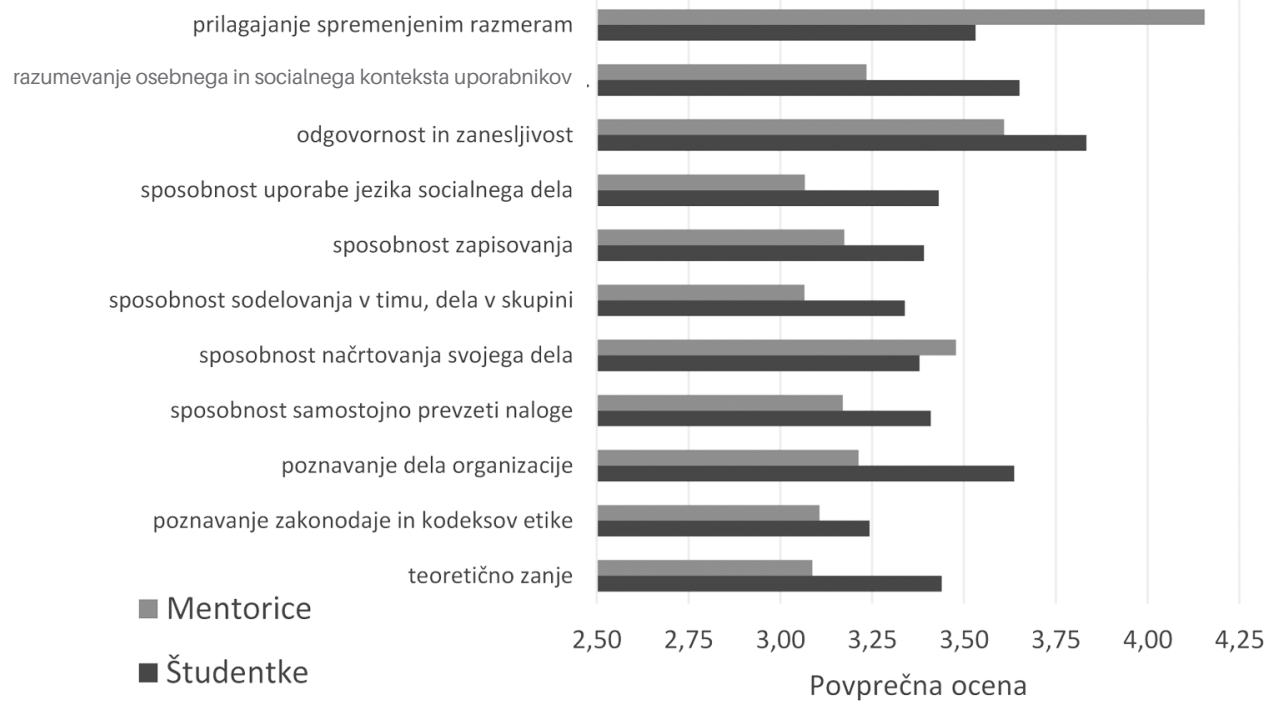

z višjimi ocenami, v povprečju tudi višje ocenjevale svoje zadovoljstvo s prakso.

V nadaljevanju predstavljamo, koliko so se pričakovanja deležnikov, povezana s praktičnim usposabljanjem, uresničila. Deležniki so podali ocene na 5 -stopenjski lestvici, kjer 1 pomeni precej manj, 3 enako, kot so pričakovale, in 5 precej več, kot so pričakovale. Vse povprečne ocene študentk so na pozitivni strani in pomenijo, da so v povprečju študentke ocenile, da so pridobile več, kot so pričakovale. Z najvišjo povprečno oceno $(M=3,83)$ je ocenjena postavka odgovornost in zanesljivost (kjer so si bile tudi pri ocenjevanju študentke najbolj enotne $)$, $\mathrm{z}$ najnižjo $(\mathrm{M}=3,24)$ pa poznavanje zakonodaje in kodeksov etike.

Iz vprašanj, ki kažejo na to, koliko so študentke pridobile na praksi, smo sestavile indeks pridobljenih kompetenc ${ }^{5}$. Študentke, ki so ocenjevale, da so v povprečju na praksi v študijskem letu $2019 / 2020$ pridobile več kompetenc, so v povprečju tudi svoje zadovoljstvo s prakso ocenile višje $(r=0,483)$.

Ocene mentoric prav tako kažejo, da so študentke po njihovi oceni pri vseh postavkah v povprečju pridobile več od pričakovanj, najnižji povprečni oceni pa sta prejeli postavki sposobnost sodelovanja v timu, dela v skupini in sposobnost za uporabo jezika socialnega dela $(M=3,07)$. $\mathrm{Z}$ daleč najvišjo povprečno oceno $(M=4,16)$ pa so mentorice ocenile, da so študentke pridobile spretnosti prilagajanja spremenjenim razmeram. Tudi v tem delu so si bile v svojih ocenah mentorice enotnejše (manjša razpršenost podatkov) kot študentke.

Primerjava povprečnih uresničitev pričakovanj (graf 3) kaže, da so skoraj glede vseh postavk študentke v povprečju ocenjevale boljše doseganje (oz.

5 Sestavile smo ga kot vsoto podanih ocen, koliko so študentke pridobile za vseh 8 postavk (Seznanitev z delom socialne delavke na določenem področju, Podpora mentorice $z$ učne baze pri opravljanju nalog za prakso, Seznanitev z zakonodajo na določenem področju, Podpora mentorice $z$ učne baze pri praktičnem delu, Seznanitev z delom/delovanjem organizacije, Omogočanje sodelovanja z uporabnikom ali uporabniki po zaslugi mentorice na učni bazi, Podpora mentorice na FSD za praktično delo in Podpora mentorice na FSD za uspešno izvedbo nalog pri praksi). 
preseganje) kot mentorice, izjemi sta postavki sposobnost za načrtovanje svojega dela in postavka prilagajanje spremenjenim razmeram. Pri tej je povprečna ocena mentoric precej (za 0,63 točke) nad povprečno oceno študentk.

\section{Izzivi praktičnega usposabljanja v času prvega vala epidemije covida-19}

Pri ocenjevanju, kakšna ovira oz. izziv pri izvedbi praktičnega usposabljanja so bili različni dejavniki, je razpršenost podatkov pri študentkah manjša kot pri mentoricah, se pravi, da so si bile v povprečju ocene študentk bolj podobne kot ocene mentoric. $V$ povprečju so študentke kot največjo oviro pri praktičnem usposabljanju omenjale Omejitve, navodila vlade in ministrstva $(M=3,91)$, sledijo Omejitve, navodila vodstva organizacije (UB) $(M=3,17)$ in Omejitve, povezane $\mathrm{z}$ uporabniki $(\mathrm{M}=3,10)$, $\mathrm{z}$ najnižjo povprečno oceno $(\mathrm{M}=2,24)$ pa so študentke ocenile Omejitve, navodila mentorice.

Pri študentkah se med indeksom ovir ${ }^{6}$ in splošnim zadovoljstvom s prakso kaže zmerna inverzna korelacija $(r=-0,452)$, to pomeni, da so tiste študentke, ki so izrazile manjše zadovoljstvo s prakso, v povprečju višje ocenile velikost ovir, s katerimi so se na praksi srečevale. Podobno kot študentke so tudi mentorice kot največjo oviro omenile Omejitve, navodila vlade, ministrstva ( $\mathrm{M}=$ $3,52)$, takoj za to postavko pa še Omejitve, povezane z uporabniki $(M=3,51)$. Sledijo ( $M=2,88)$ Omejitve, navodila vodstva organizacije (UB) in z najnižjo povprečno oceno $(M=2,35)$ Omejitve, navodila neposredno nadrejenega.

Primerjava ocen mentoric in študentk (graf 4) je pokazala, da so študentke v povprečju kot nekoliko večji oviri kot mentorice omenile omejitve vlade oz. ministrstva in vodstva učne baze, nasprotno pa so mentorice kot večjo oviro omenile tudi omejitve, povezane z uporabniki.

Graf 4: Primerjava ocen študentk in mentoric glede velikosti ovir.

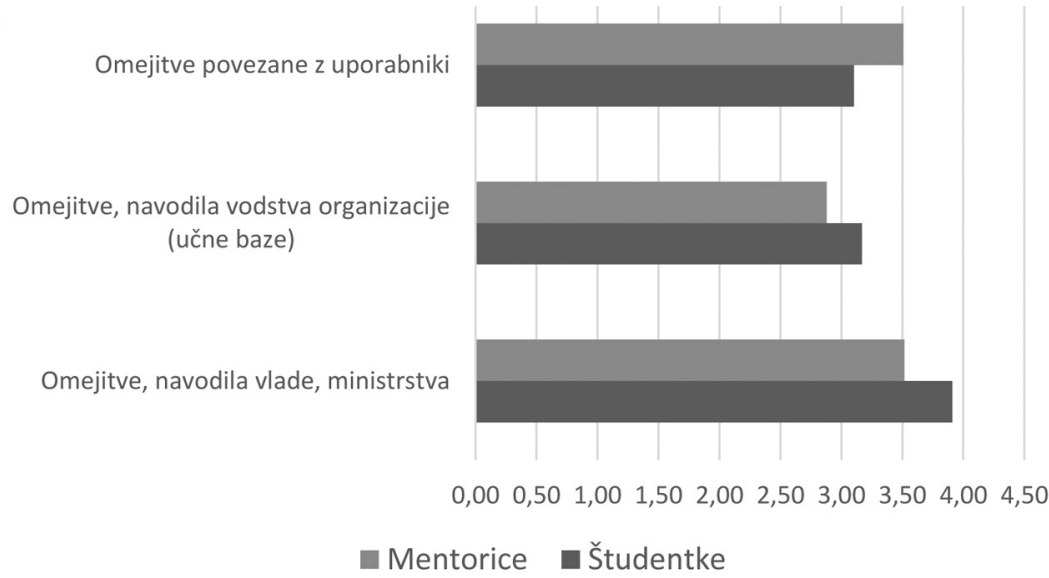

Če pogledamo še analizo odprtih odgovorov mentoric in študentk glede izzivov, s katerimi so se srečevale na praksi, vidimo, da je bila vsem sodelujočim v raziskavi največji izziv zaprtost učnih baz oz. njihovi ukrepi, ki so jih te v povezavi

6 Sestavile smo ga kot vsoto podanih ocen velikosti za vse štiri ovire (vlada, organizacija, mentorica in uporabniki) skupaj. 
z ukrepi vlade za zajezitev širjenja covida-19 sprejele (ti dve kodi se pojavita $\mathrm{v}$ nekaj manj kot polovici vseh analiziranih dokumentov).

Ker smo dom starejših občanov zaprli, je bil onemogočen del praktičnega dela. (A5.MUB)

To je za študentke pomenilo številne ovire za izvedbo prakse, kot so (pre)malo oz. nič osebnega stika z uporabniki, saj so bile prisiljene sodelovanje z njimi izvajati le na daljavo (s pomočjo informacijsko-komunikacijske tehnologije), prikrajšanost za bolj poglobljeno spoznavanje določenih področij dela socialnega dela, pomanjkanje možnosti za izvedbo strnjenega dela prakse, prepoved opravljanja prakse v živo.

V času, predvidenem za prakso, do nje ni prišlo. S študentko smo bili v stiku kasneje. Iskali naj bi možnosti, kako izvajati prakso na daljavo. Vendar na daljavo po mojem mnenju kvalitetna praksa ni mogoča, saj je ravno cel spekter dogajanja, vzdušje, sodelovanje v primerih, biti prisoten, prisotna pri timskih strokovnih srečanjih, debatah, itd. tisto, kar praksa ponudi. (A48.MUB)

Dve mentorici s FSD sta kot izziv navedli tudi to, da nekatere učne baze sodelovanja študentk z uporabniki na daljavo niti niso omogočale in so tako študentke ostale tako rekoč brez prakse. Vsi ti izzivi so zato povzročili, da so študentke imele težave z nabiranjem zadostnega števila ur za prakso ter s samo izvedbo nalog (ki jih niso mogle izvesti na način in v obliki, kot je bilo to prvotno predvideno). To je večalo negotovost študentk glede vprašanja, ali bodo prakso sploh lahko opravile, in jih spravljalo v še dodatno stisko.

Nevednost na začetku, kako naj bi vse skupaj potekalo - če praksa sploh bo, kako jo bom lahko opravljala, s kom, na kakšen način. (A75.Š)

Izziv je bilo za nekatere študentke tudi samo sodelovanje z uporabniki (koda se pojavi v petini analiziranih dokumentov), predvsem zato, ker se nekateri niso odzivali na delo na daljavo oz. niso želeli/mogli s študentko sodelovati na tak način (specifične potrebe uporabnikov, neopremljenost učnih baz oziroma uporabnikov z informacijsko-komunikacijsko tehnologijo, nezmožnost uskladitve termina s študentko ipd.). Posledica tega je bil lahko predčasen konec prakse.

On-line srečanja z uporabniki - težava, da nimajo vsi dostopa do telekomunikacijskih sredstev, težje jih je motivirati, nekateri nočejo sodelovati, zato je bilo potrebno ure nabirati drugje, to je vplivalo na izvedbo nalog. (A21.Š)

Mentorice na učnih bazah in fakulteti pa so navajale tudi izzive, povezane z izvajanjem mentorstva, ki so se pojavili predvsem kot posledica preobremenjenosti z delom, zaradi spremenjenega načina dela (spremembe v načinu delovanja učne baze, študij na daljavo, potreba po dodatni podpori študentkam zaradi vseh novih izzivov, ki jih je praksa prinesla, okužbe med zaposlenimi ipd.) pa tudi različnih osebnih okoliščin (pripadnost bolj rizični skupini v primeru okužbe, šolanje in varstvo otrok doma ipd.).

Poleg ostalega dela - reorganizacije dela z uporabniki - še iskati primeren način za delo s študentom ter delo študenta $\mathrm{z}$ uporabnikom, $\mathrm{s}$ katerim odnos še ni bil vzpostavljen. Včasih ni bilo mogoče zagotoviti študentom dovolj pozornosti in so obviseli nekje vmes. Razumljivo, da tudi motivacija upade. (A94.MUB) 
Zato so nekatere mentorice tako na fakulteti kot na učnih bazah manj sodelovale, to pa je bil še dodatni izziv. Nekatere mentorice na učnih bazah in študentke so poročale, da je preobremenjenost mentoric $z$ delom zato povzročila tudi pomanjkanje časa za kakovostno izvajanje mentorstva. Dve mentorici na učnih bazi sta omenili, da bi si želeli več informacij o poteku prakse od FSD, ena pa je kot izziv omenila, da na učni bazi ni zaposlene socialne delavke in zato študentki ni uspelo zares spoznati dela socialne delavke. Po drugi strani pa so posamezne izzive nekatere mentorice na učni bazi prepoznavale tudi pri samih študentkah, npr. nepripravljenost študentk za delo na daljavo, njihova neodzivnost, hipna odločitev študentke za opravljanje prakse na izbrani učni bazi, zato se ta baza ni mogla kakovostno pripraviti na samo prakso, predvsem pa so zaznavale preobremenjenost študentk z obveznostmi za študij.

Študentki naj bi bili v času epidemije precej obremenjeni z drugimi aktivnostmi, povezanimi s FSD, tako da smo težko našle termine in izbrale, kaj bi delale (telefonski pogovori z uporabniki, komunikacija po mailu, sprehodi $\mathrm{z}$ uporabniki) - vsega tega v času epidemije nismo mogle izvajati. Torej, čas prakse naj bi bil namenjen času prakse. (A94.MUB)

\section{Predlogi za izvedbo prakse $v$ času izrednih razmer}

Analiza odprtih odgovorov sodelujočih v raziskavi je pokazala tudi na nekaj predlogov, o katerih bi veljajo razmisliti pri izvedbi prakse v času izrednih razmer. Pri vseh sodelujočih v raziskavi je prevladoval predlog, povezan s potrebo po prilagoditvi ur in nalog za prakso (predvsem se jim je zdelo, da je nalog preveč) - ti dve kodi se pojavita v nekaj več kot petini vseh analiziranih dokumentov.

Prosim, prosim, premislite, ali so dodatne naloge za učno mapo res potrebne? Osebno menim, da študentje veliko odnesemo, če se lahko vključimo dejansko v dejavnosti baze in ne samo izpolnjujemo naloge za v mapo. Sploh v izrednih razmerah, ko je vse bolj kaotično in je lažje, če se mi prilagajamo bazi, kot pa ona nam, da nam omogoči podporo pri izpeljavi nalog. (A94.Š)

Drugi predlogi pa so bili precej različni. Študentke so denimo predlagale, da bi bilo treba narediti nabor učnih baz, ki tudi v času izrednih razmer omogočajo prakso v živo ali vsaj na daljavo. Med posameznimi predlogi so bili še: sprotno informiranje študentk o poteku prakse, upoštevanje specifičnih okoliščin študentk pri načrtovanju in izvedbi prakse, omogočanje enakih pogojev za opravljanje prakse (npr. nekateri so prakso lahko opravili v roku, drugim se je zavlekla v poletje), možnost opravljanja prakse v domačem okolju, prilagoditev izpitnih rokov. Nekatere mentorice na učnih bazah so pohvalile odziv FSD na nastalo situacijo, a hkrati opozorile, da bi si želele ( ̌̌e) več spodbujanja študentk za njihovo aktivacijo. Poudarile so, da bi si želele imeti izdelan protokol za potek prakse študentk v času izrednih razmer, ki bi učnim bazam omogočal lažjo prilagoditev prakse, študentke pa bi bile na to bolj pripravljene, in vključitev mentoric z učnih baz v načrtovanje prakse. 
Glede na to, da smo centri za socialno delo javni zavodi in se moramo ravnati po navodilih ministrstev, bi morda lahko FSD pripravil protokol dela študentk na praksi za primer ponovne epidemije, ki bi našim nadrejenim olajšal možnost vključevanja študentk. Res je, da je prakso možno izvajati tudi na daljavo, vendar to ni to. To je skrajna rešitev, ko ni nobene druge. Če že ščitimo ranljive skupine, dejansko ne moremo spuščati v hišo zunanjih ljudi. Kako s tem ravnati? Ne vem. (A48.MUB)

\section{Omejitve raziskave}

Zbiranje podatkov je večinoma potekalo julija in avgusta 2020 (takoj po koncu prvega vala epidemije). To pomeni, da so bili vtisi še sveži, lahko pa pomeni tudi, da so bili nekateri v tem času preobremenjeni (za takšne »dodatne aktivnosti« in si s tem morda lahko ob že omenjeni splošni nenaklonjenosti sodelovanju v spletnih anketah pojasnimo tudi dokaj velik osip - predvsem na ravni študentk v 1. in 2. letniku) ali pa so lahko imeli nekateri deležniki prakse zaradi dopustov ipd. omejene možnosti sodelovanja v raziskavi. Ker je bilo anketiranje anonimno, smo s ponovnimi povabili (tako prek spletnega referata kot tudi prek mentoric s FSD) k sodelovanju lahko ponovno vabili zgolj celotno populacijo (vabilo smo trikrat ponovili). Kljub želji (in dodatnim naporom) po popisu celotne populacije smo s spletno anketo k sodelovanju pridobili le bolj motiviran (s pozitivnimi in negativnimi izkušnjami) del celotne populacije.

Čeprav lahko iz podatkov razberemo različnost odgovorov (in demografskih značilnosti sodelujočih) na eni strani ter primerljivost podatkov s predhodnimi podobnimi raziskavami na drugi strani, zaradi samega načina zbiranja podatkov in osipa obstaja nevarnost morebitne pristranosti rezultatov (v pozitivno smer). K temu pa lahko pripomore tudi to, da so izvedbo praktičnega usposabljanja ocenjevale tudi študentke 1. in 2. letnika, ki so vsaj del prakse (od novembra 2019 do februarja 2020) opravile še pred pandemijo. Skoraj polovico podatkov je prispevala generacija 3. letnika, ki je imela največ izkušenj s praktičnim usposabljanjem v času covida-19 (študentke tega letnika imajo največji obseg števila ur prakse, za seboj pa že dve leti izkušenj s prakso v običajnih razmerah), zato ocenjujemo, da so podatki kljub »neuravnoteženi« zastopanosti študentk različnih letnikov dovolj kakovostni za namen naše analize. Ker pa se ob pregledu ocen (povprečnih ocen po letnikih) mnenja med posameznimi letniki (v vseh letnikih so študentke poročale tako o pozitivnih kot tudi o negativnih vidikih in različnih izkušnjah) $v$ grobem niso občutno razlikovala, ocenjujemo, da navedeno ni (pre)velik problem.

\section{Sklep}

Pojav pandemije covida-19 je zelo vplival na študijski proces na FSD, še posebej na praktično usposabljanje, v katerem je udeleženih veliko deležnikov. Opažamo spremembe (v primerjavi s praktičnim usposabljanjem pred covidom-19) tudi pri zastopanosti različnih učnih baz in področjih dela pri praktičnem usposabljanju študentk. Nekatere raziskave (Banks idr. 2020; Harrikari, Romakkani- 
emi, Tiitinen in Ovaskainen, 2021; Morley in Clarke, 2020) že kažejo na to, da je bilo to obdobje še posebej zahtevno za vse ključne deležnike prakse - tako uporabnike (pri katerih so se obstoječi izzivi lahko povečali in pojavili novi) kot tudi mentorice (ki so bile prisiljene ob oteženem usklajevanju delovnega in zasebnega življenja iskati nove načine zagotavljanja podpore in pomoči, predvsem povezanih z uporabo informacijsko-komunikacijske tehnologije in delom zunaj pisarn, npr. od doma, pred centrom za socialno delo, ter pokrivati povečano število (bolniških) odsotnosti v kolektivu) in študentke. Študentke so doživljale stres tako zaradi negotovosti, dodatnih obremenitev zaradi prehoda na študij na daljavo (tako na fakulteti kot na učni bazi), ki jim je, vsaj po nekaterih ocenah študentk, prinesel večji obseg dela za študij, kot tudi zaradi različnih osebnih okoliščin (izguba študentskega dela, bivališča, neustrezne družinske razmere za študij na daljavo ipd.).

Rezultati raziskave o doživljanju praktičnega usposabljanja za socialno delo v Sloveniji z vidika mentoric in študentk kažejo, da so bile mentorice $s$ prakso v študijskem letu 2019/2020 zadovoljnejše kot študentke, čeprav se je povprečna ocena študentk tudi nagibala k zadovoljstvu. Mentorice so bile pri podajanju svoje ocene manj kritične do izvedbe praktičnega usposabljanja v času covida-19 ali pa so morda bolje (kot študentke) opazile, kaj vse so študentke med prakso v tem času pridobile. Razlog za manj kritično ocenjevanje izvedbe praktičnega usposabljanja pri mentoricah pa je morda tudi drugačen pogled na stanje in dejanske možnosti za praktično usposabljanje v času covida-19. Razlogov za razlike v povprečnih ocenah $\mathrm{v}$ tej raziskavi nismo ugotavljali, bi bilo pa v prihodnje zanimivo analizirati, kako to, da je povprečna ocena prakse študentk v študijskem letu 2019/2020 $(M=3,66)$ opazno nižja od tiste, ki so jo študentke podale v študijskem letu 2014/2015 in je znašala 4,09 (Interni podatki Centra za praktični študij, neobjavljeno).

Morda si navedeno lahko razlagamo tako, da je praksa (ali vsaj del nje) potekala na daljavo, to pa je po poročanju študentk povzročalo številne izzive (npr. manj ali nič stika z uporabniki, prikrajšanost za spoznavanje določenih nalog socialnih delavk, manjše število opravljenih ur prakse, težave z izvedbo nalog za prakso). Zanimivo pa pri mentoricah v povprečnih ocenah ni opaziti takšnega zmanjšanja oz. poslabšanja zadovoljstva. Morda lahko navedeno pripišemo (vsaj delno) tudi ugotovljeni korelaciji pridobljenih kompetenc z zadovoljstvom študentk s prakso ter na splošno manjšimi možnostmi za neposredni stik z uporabniki (med praktičnim usposabljanjem).

So pa podatki pokazali, da so študentke zaradi situacije, $v$ kateri so opravljale praktično usposabljanje (pandemija), pridobile več novih znanj, ki jih lahko delimo na vsebinska (povezana $\mathrm{z}$ uporabniki in njihovimi življenjskimi svetovi) in znanja, povezana z uporabo informacijsko-komunikacijske tehnologije ter drugimi inovativnimi pristopi k sodelovanju $\mathrm{z}$ uporabniki in mentoricami. Prav tako so (kot prikazujejo rezultati v točki 5.2) študentke dodatno razvile predvsem sposobnosti za prilagajanje spremenjenim razmeram, iznajdljivost ter odgovornost in zanesljivost. 
Pridobljeni podatki kažejo, da so si bile glede na uporabljeno stopnjo razpršenosti podatkov (sd) mentorice v odgovorih načelno bolj podobne kot študentke, to pa ne velja za ocenjevanje velikosti ovir. Tu se je pokazalo, da so mentorice v povprečju bolj različno doživljale, kako velika ovira so določene omejitve, in domnevamo, da so potem v skladu s tem tudi delovale. To sovpada tudi s povratnimi informacijami o tem, da so bili pogoji za delo z uporabniki in opravljanje praktičnega usposabljanja na različnih učnih bazah (tudi znotraj istovrstnih organizacij, npr. enote centrov za socialno delo) različni.

Ugotovile smo tudi, da so študentke, ki so kot višje ocenile različne ovire in omejitve, zadovoljstvo s prakso v povprečju ocenjevale kot nižje (višje zaznane ovire so torej povezane $\mathrm{z}$ nižjim zadovoljstvom). Iz tega pa bi težko predpostavljale, ali to kaj pove o velikosti ovir ali morda bolj o sami usposobljenosti študentk, zato to raje prepuščamo nadaljnjim raziskavam. Hkrati pa ugotovitve raziskave kažejo, kar podpirajo tudi predhodne ugotovitve o ključni vlogi dobre mentorske podpore (gl. npr. Fourtune, McCarthy in Abramos, 2001; Raskin, Wayne in Bogo, 2008; Cleak in Smith, 2012; Goodyear, 2014; Bogo, 2014, 2015; Nordstrand, 2017; McSweeney in Williams, 2018), namreč, da je pri spoprijemanju študentk z izzivi na praksi ključna podpora mentoric (s fakultete in učne baze), saj tako dobijo znanje, kako se na izzive odzvati. $V$ pridobljenih podatkih se kaže tudi pomembnost dodatnega razmisleka o nalogah (številu in obsegu), večjem poudarku spoznavanja zakonodajnega okvirja dela socialnih delavk ter o dodatnem motiviranju in spodbujanju študentk na fakulteti za še večjo zavzetost za praktično usposabljanje.

Pandemija covida-19 je res presenetila celoten svet, a nas tudi naučila, da nimamo vedno vnaprej pripravljenih odgovorov na nove situacije. V socialnem delu že dolgo vemo, da socialne delavke nimamo vnaprej opredeljenih odgovorov, ampak moramo želene izide in odgovore šele soustvariti skupaj z našimi sogovorniki (Čačinovič Vogrinčič in Mešl, 2019). Izkušnje in znanje, ki smo jih pridobili z izvedbo praktičnega usposabljanja v prvem valu epidemije, pričajo o tem, da bi bilo vredno razmisliti o izdelavi protokola za izvedbo prakse $v$ času izrednih razmer tako na FSD kot tudi na posameznih učnih bazah. Protokol bi lahko vseboval nabor možnih oblik prakse in minimalen obseg ur, ki bi še vedno omogočale pridobitev ustreznih kompetenc, prilagoditve nalog, usposabljanje študentk za sodelovanje z uporabniki na daljavo ipd. Pri tem pa menimo, da je v načrtovanje protokola treba vključiti vse deležnike prakse (študentke, mentorice z učnih baz in FSD ter uporabnike) in da kljub izdelanemu protokolu ne pozabimo na temeljno usmeritev socialnega dela, ki je neposredno odzivanje na vsakdanje potrebe in izzive ljudi v skupnosti.

\section{Viri}

Amadasun, S. (2020). COVID-19 pandemic in Africa: what lesssons for social work education and practice. International Social Work 64(2), 1-5.

Azman, A., Singh, P. S. J., Parker, J., \& Crabtree, S. A. (2020). Addressing competency requirements of social work students during the COVID-19 pandemic in Malaysia. Social Work Education, 39(8), 1058-1065. 
Banks, S., Cai, T., de Jonge, E., Shears, J., Shum, M., Sobočn, A. M., Strom, K., Truell, R., Ǔriz, M. J., \& Weinberg, M. (2020). Practising ethically during COVID-19: social work challenges and responses. International Social Work, 63(5), 569-583.

Bogo, M. (2014). Achieving competence in social work through field education. Toronto: University of Toronto Press.

Bogo, M. (2015). Field education for clinical social work practice: best practices and contemporary challenges. Clinical Social Work Journal, 43(3), 317-324.

Buchanan, C. S., \& Bailey-Belafonte, S. J. (2021). Challenges in adapting field placement during a pandemic: a Jamaican perspective. International Social Work, 64(2), 285-288.

Center za praktični študij. Evalvacija študijske prakse 2014/2015 (interni podatki, neobjavljeno). Ljubljana: FSD.

Cleak, H., \& Smith, D. (2012). Student satisfaction with models of field placement supervision. Australian Social Work, 65(2), 243-258.

Cleak, H., Hawkins, L., Laughton, J., \& Williams, J. (2015). Creating a standardised teaching and learning framework for social work field placements. Australian Social Work, 68(1), 49-64.

Čačinovič Vogrinčič, G., \& Mešl, N. (2019). Socialno delo z družino: soustvarjanje želenih izidov in družinske razvidnosti. Ljubljana: Fakulteta za socialno delo.

Dempsey, A., Lanzieri, N., Luce, V., De Leon, C., Malhotra, J., \& Heckman, A. (2021). Faculty respond to COVID-19: reflections-on-action in field education. Clinical Social Work Journal. Pridobljeno 31. 8. 2021 s https://doi.org/10.1007/s10615-021-00787-y

Dominelli, L., Harrikari, T., Mooney, J., Leskošek, V., \& Kennedy Tsonuda, E. (2020). Covid-19 and social work: a collection of country reports. Pridobljeno 20. 5. $2021 \mathrm{~s} \mathrm{https://www.}$ drugsandalcohol.ie/32880/1/IASW-COVID-19-and-Social-Work-Country-Reports.pdf

Fortune, A. E., McCarthy, M., \& Abramson, J. S. (2001). Student learning processes in field education: Relationship of learning activities to quality of field instruction, satisfaction, and performance among MSW students. Journal of Social Work Education, 37(1): 111-124.

Goodyear, R. K. (2014). Supervision as pedagogy: attending to its essential instructional and learning processes. Clinical Supervisor, 33(1), 82-99.

Govekar-Okoliš, M., \& Gruden, U. (2011). Ugotovitve in spoznanja z izobraževanja mentorjev za praktično usposabljanje študentov. Andragoška spoznanja, 17(1), 62-73.

Harrikari, T., Romakkaniemi, M., Tiitinen, L., \& Ovaskainen, S. (2021). Pandemic and social work: exploring Finnish social workers'experiences through a SWOT analysis. British Journal of Social Work, 1, 1-19.

Kodele, T., \& Mešl, N. (2015). Refleksivna uporaba znanja v kontekstu praktičnega učenja. Socialno delo, 54(3-4), 189-203.

Kourgiantakis, T., \& Lee, E. (2020). Social work practice education and training during the pandemic: disruptions and discoveries. International Social Work, 63(6), 761-765.

Kourgiantakis, T., Sewell, K. M, Hu, R., Logan, J., \& Bogo, M. (2020). Simulation in social work education: a scoping review. Research on Social Work Practice, 30(4), 433-450.

Lee, E., Bogo, M., \& Tsang, A.K.T. (2020). A Socially Just and Culturally Competent Practice: Toward Holistic Competence in Social Work. V Brandell, J. R. (ur.) Theory \& Practice in Clinical Social Work (3izd.) (str. 567-88). San Diego: Cognella.

McSweeney, F., \& Williams, D. (2018). Social care students' learning in the practice placement in Ireland. Social Work Education, 37(5), 581-596.

Mesec, M. (2015). Praktični študij na fakulteti za socialno delo. Socialno delo, 54(3-4), 139-248.

Mesec, M., Poštrak, M., Škerjanc, J., Jagrič, A., Videmšek, P., \& Rape Žiberna, T. (2019). Priročnik za Prakso 1. Ljubljana: Fakulteta za socialno delo, Center za praktični študij.

Morley, C., \& Clarke, J. (2020). From crisis to opportunity? Innovations in Australian social work field education during the COVID-19 global pandemic. Social Work Education, 39(8), 1048-1057.

Nacionalni inštitut za javno zdravje (2021). Ocena potreb po psihosocialni podpori v drugem valu epidemije covida-19. Pridobljeno 31. 8. $2021 \mathrm{~s} \mathrm{http://www.dps.si/za-psihologe/koro-}$ navirus/ocena-potreb-po-psihosocialni-podpori/ 
Nadeak, B. (2020). The effectiveness of distance learning using social media during the pandemic period of COVID-19: a case in Universitas Kristen Indonesia. International Journal of Advanced Science and Technology, 29(7), 1764-1772.

Nordstrand, M. (2017). Practice supervisors' perceptions of social work students and their placements - an exploratory study in the Norwegian context. Social Work Education, 36 (5), 481-494.

Petra, M. M., Tripepi, S., \& Guardiola, L. (2020). How many hours is enough? The effects of changes in field practicum hours on student preparedness for social work. Field Educator, 10(1), 1-21.

Rape Žiberna, T. (2019). Konceptualizacija timskega dela v socialnem delu v Sloveniji (doktorsko delo). Ljubljana: Fakulteta za socialno delo.

Rape Žiberna, T., \& Žiberna, A. (2017). Kaj je pomembno za dobro študijsko prakso v socialnem delu. Pogled mentoric z učnih baz. Socialno delo, 56(3), 157-178.

Raskin, M. S., Wayne, J., \& Bogo, M. (2008). Revisiting field education standards. Journal of Social Work Education, 44(2), 173-188.

Sarbo, R., \& Unwin, P. (2021). Complexities in student placements under COVID-19 moral and practical considerations. Frontiers in Psychology, 4(6), 654-665. Pridobljeno 30. 8. 2021 s https://www.frontiersin.org/articles/10.3389/feduc.2021.654843/full

Shulman, L. S. (2005). Signature pedagogies in the professions. Journal of the American Academy of Arts \& Sciences, 134(3), 52-59.

Tashfeen, A. (2018). Teaching evaluation and student response rate. PSU Research Review, 2(3), 206-211.

University of California (2021). Completion and response rates of UC surveys. Pridobljeno 26. 8. $2021 \mathrm{~s}$ https://www.universityofcalifornia.edu/infocenter/completion-and-response-rates-uc-surveys?fbclid=IwAROw1ANiAHzWgRzkKMvD2iqsaoCAjQ2qU5zoxZAPvrUzFBsp8oHqFm0i51s

Walsh, C. A., Gulbrandsen, C., \& Lorenzetti, L. (2019). Research practicum: an experiential model for social work research. Sage Open, 9(2), 1-11.

Zurlo, M. C., Cattaneo Della Volta, M. F., \& Vallone, F. (2020). COVID-19 student stress questionnaire: development and validation of a questionnaire to evaluate students' stressors related to the Coronavirus pandemic lockdown. Frontiers in Psychology, 11, 576758. Pridobljeno 31. 8. $2021 \mathrm{~s} \mathrm{https://www.frontiersin.org/articles/10.3389/fpsyg.2020.576758/full}$ 
